\title{
Virtual Reality for Motor Rehabilitation of Children with Down Syndrome: Systematic Review
}

\author{
REHAM A. MOHAMED, M.Sc.*; SAMIA A. ABD EL-RAHMAN, Ph.D.** and MAYA G. ALY, Ph.D.** \\ The Departments of Physical Therapy, Damanhoor Hospital* and Physical Therapy for Pediatrics, Faculty of Physical Therapy, \\ Cairo University**
}

\begin{abstract}
Background: Down syndrome is one of the most common genetic causes of developmental delays. Virtual reality is an innovative tool of rehabilitation based on computer technology. It has been applied in the rehabilitation of many developmental areas.

Aim of Study: To systematically review the available studies on the effect of virtual reality in motor rehabilitation of children with Down syndrome.

Patients and Methods: An electronic search was made in Cochrane (CENTRAL), Pedro, PubMed (MEDLINE), Google scholar and TRIP databases from July 2017 to July 2018, in addition to manual search in reference lists of the included studies. The inclusion criteria were: Published studies of any design which investigatethe effect of virtual reality on motor rehabilitation of children with Down syndrome, reviews studies were excluded. The outcome measures were: Balance, sensorimotor functions, coordination, strength andagility.Two independent reviewers assessed the methodological quality and extracted data from the included studies. Score differences were discussed between the two reviewers and disagreements were revealed by consultation with a third author until consensus was reached.
\end{abstract}

Results: A total number of 30 records, 7 of them were duplicated, 19 of them were excluded after screened the title and abstract. Only 4 articles met the inclusion criteria; 2 were randomized controlled trials, one was quasi-experimental study and one was case report. One study fulfills the criteria of high methodological quality; two studies were of moderate quality and one of weak quality. Descriptive analysis was performed as data extracted from the included studies heterogeneous.

Conclusion: Despite the few number of studies found and the heterogeneity present between its characteristics, the methodological quality of the included study gave moderate evidence regarding the effectiveness of virtual reality in motor rehabilitation of children with Down syndrome. Further well designed randomized controlled trials on the effectiveness of virtual reality on children with Down syndrome are necessary.

Key Words: Systematic review - Children - Down syndromeRehabilitation - Virtual reality.

Correspondence to: Dr. Reham A. Mohamed, The Department of Physical Therapy, Damanhoor Hospital

\section{Introduction}

DOWN syndrome (DS) is a genetic disorder caused by abnormal cell division results in extra chromosome 21. It varies in severity, lifelong, intellectual disability and developmental delays [1].Children with DS have often delayed development relative to age-matched typically developing peers; because of poor muscle tone, poor balance, postural instability and incoordination, but despite these delays; they can learn to participate in physical exercise activities like other children $[2,3]$.

Physical rehabilitation of children with DS aims to developmotor skills, increase muscle tone and strength, and to improve posture and balance [4] Virtual reality (VR) is a computer technology that provides a realistic and immersive simulation of a three-dimensional environment that enables users to have improved experiences of reality by creating a sense of "presence". There are many types of VRincluding fully immersive VR, Non-immersive VR, Collaborative VR, Web-based VR, Augmented reality and Wii Games [5]. It has been used in many medical sets to help treat anxiety disorders, control pain, support physical rehabilitation and wound care [6]

A previous systematic review [7] was conducted in 2011, the authorsconcluded that VR-based rehabilitation in children with a variety of sensorimotor deficits is feasible and safe; however, higher quality research is necessary before the use of VR in pediatric rehabilitation. The effectiveness of VR in motor rehabilitation of children with DS has not been demonstrated in previous reviews. Thus, this systematic review aimed to verify the effects of VR on motor abilities of children with DS. 


\section{Patients and Methods}

\section{Search strategy for identification of relevant} studies:

Electronic search was done in Cochrane (CENTRAL), Pedro, PubMed (MEDLINE), Google scholar and TRIP databases from July 2017 to July 2018 using the following keyword: "Down syndrome", "trisomy 21", "motor rehabilitation", "virtual reality", "Wii game". No search restrictions were applied regarding language or year of publication.

Studies were included in this review if they met the following criteria: Published studies of any design except reviews; studying the effect of virtual reality of any type on motor abilities includingbalance, sensorimotor function, postural stability, upper limb coordination, muscle strength of children with Down syndrome. Published abstracts without available full text, studies on adults with Down syndrome, and studies measure outcomes not related to the scope of this review were excluded.

Two authors independently evaluated each title and abstract identified in the searchagainst the eligibilitycriteria. The full text was obtained for complete analysis. Two authors independently extracted data from the included studiesand assessed its methodological quality. Manual search was done byrevising reference lists of the included studies.

\section{Quality assessment:}

The methodological quality of the included studies was critically appraised by two independent reviewers by applying the American academy for cerebral palsy and developmental medicine (AACPDM) andPhysical therapy evidence database (PEDro) scales [8,9] . For rating methodological quality, the following classification was used:

1- The AACPDM score of (score <3)indicated Weak quality; (4 or 5) indicated Moderate quality; (6 or 7) indicated Strong quality [10].

2- PEDro score of $(<4)$ indicated poor quality; (4$5)$ fair quality; (6-8) good quality and (9-10) excellent quality [11].

3- Score differences were discussed between the two reviewers and disagreements were revealed by consultation with a third author until consensus was reached.
Levels of evidence:

For interpretation of results, the following levels of evidence were used [12]:

- Strong evidence $=$ Consistent findings among multiple high-quality studies (6 on PEDro scale).

- Moderate evidence=Consistent findings among multiple lower quality studies $(<6$ on PEDro scale) and/or one higher quality study.

- Limited evidence=One lower quality study.

- Conflicting evidence=Inconsistent findings amongst multiple studies.

- No evidence $=$ No evidence among studies.

\section{Results}

The search results are presented in the PRISMA flow chart (Fig. 1). Thirty studies were identified in the initial search; four studies $[\mathbf{1 3 , 1 4 , 1 5 , 1 6 ]}$ were relevant and selected for detailed analysis. Data from each study were then extracted. Two independent reviewers scored each article using the AACPDM and PEDro scale.

Results of the quality assessment of the included studies by AACPDM scale are presented in Table (1). Only one study [1s of the four included studies fulfill the criteria of high methodological quality which judged as strong (yes on 6 questions), two studies [13,14] fulfill the criteria of moderate methodological quality (yes on 4-5questions), andone study [16] fulfill the criteria of weak methodological quality (yes on 3questions).

Results of the quality assessment of the included studies by PEDro scale are presented in Table (2).

Records identified from Databases search $(\mathrm{n}=30)$

PEDro (4), Cochrane (4), PubMed

(10), Google Scholar (9), TRIP (3)

\begin{tabular}{|c|c|c|}
\hline $\begin{array}{c}\text { Records Screened by } \\
\text { titles and abstracts } \\
(n=30)\end{array}$ & $\begin{array}{l}\text { Records Duplicated }(n=7) \\
\text { Records Excluded }(n=19)\end{array}$ \\
\hline
\end{tabular}

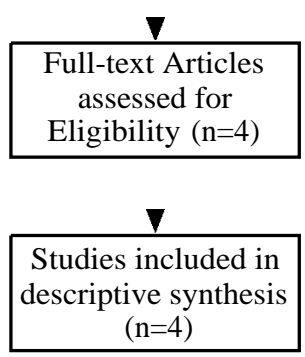

Fig. (1): The PRISMA flow chart of the studies included in the review. 
Table (1): AACPDM scores of the four included studies.

\begin{tabular}{|c|c|c|c|c|}
\hline Questions & $\begin{array}{l}\text { Abdel } \\
\text { Rahman } \\
2010[13]\end{array}$ & $\begin{array}{l}\text { Wuang } \\
\text { et al., } \\
2011 \text { [14] }\end{array}$ & $\begin{array}{l}\text { Lin and } \\
\text { Wuang } \\
2012 \text { [15] }\end{array}$ & $\begin{array}{l}\text { Patti } \\
\text { et al., } \\
2012[16]\end{array}$ \\
\hline $\begin{array}{l}\text { 1- Were inclusion and exclusion criteria of the } \\
\text { study population well described and followed? }\end{array}$ & Yes & Yes & Yes & Yes \\
\hline $\begin{array}{l}\text { 2- Was the intervention well described and was } \\
\text { there adherence to the intervention assignment? } \\
\text { (For two-group designs, was the contro l expo- } \\
\text { sure also well described?) }\end{array}$ & Yes & Yes & Yes & Yes \\
\hline $\begin{array}{l}\text { 3- Were the measures used clearly described, valid, } \\
\text { and reliable for measuring the outcomes of } \\
\text { interest? }\end{array}$ & Yes & Yes & Yes & Yes \\
\hline $\begin{array}{l}\text { 4- Was the outcome assessor unaware of the inter- } \\
\text { vention status of the participants (i.e. was there } \\
\text { blind assessment)? }\end{array}$ & No & Yes & Yes & No \\
\hline $\begin{array}{l}\text { 5- Did the authors conduct and report appropriate } \\
\text { statistical evaluation including power calcula- } \\
\text { tions? }\end{array}$ & No & No & No & No \\
\hline $\begin{array}{l}\text { 6- Were dropout/loss to follow-up reported and } \\
\text { less than } 20 \% \text { ? For two-group designs, was } \\
\text { dropout balanced? }\end{array}$ & Yes & Yes & Yes & No \\
\hline $\begin{array}{l}\text { 7- Considering the potential within the study de- } \\
\text { sign, were appropriate methods for controlling } \\
\text { confounding variables and limiting potential } \\
\text { biases used? }\end{array}$ & No & No & Yes & No \\
\hline Total score $(0-7)$ & 4 & 5 & 6 & 3 \\
\hline Quality & Moderate & Mod erate & Strong & Weak \\
\hline
\end{tabular}

Table (2): PEDRO scores of the included randomized studies.

\begin{tabular}{|c|c|c|c|}
\hline Criteria & $\begin{array}{l}\text { Abdel Rahman } \\
\quad 2010[13]\end{array}$ & $\begin{array}{l}\text { Wuang et al., } \\
2011 \text { [14] }\end{array}$ & $\begin{array}{l}\text { Lin and Wuang } \\
2012[15]\end{array}$ \\
\hline 1- Specified eligibility criteria* & Yes & Yes & Yes \\
\hline 2- Random allocation of participant & Yes & Yes & Yes \\
\hline 3- Concealed allocation & No & No & No \\
\hline 4- Similar prognosis at baseline & Yes & Yes & Yes \\
\hline 5- Blinded participant & No & No & No \\
\hline 6- Blinded therapists & No & No & No \\
\hline 7- Blinded assessors & No & Yes & Yes \\
\hline $\begin{array}{l}\text { 8- More than } 85 \% \text { follow-up for at least one } \\
\text { key outcome. }\end{array}$ & Yes & Yes & Yes \\
\hline 9- 'Intention to treat' analysis. & Yes & No & Yes \\
\hline $\begin{array}{l}\text { 10- Between group statistical analysis for at } \\
\text { least one key outcome. }\end{array}$ & Yes & Yes & Yes \\
\hline $\begin{array}{l}\text { 11- Point estimates of variability for at least } \\
\text { onekey outcome }\end{array}$ & Yes & Yes & Yes \\
\hline Total PEDro score $($ /10) & 6 & 6 & 7 \\
\hline Quality & Good & Good & Good \\
\hline
\end{tabular}

*Item 1 does not contribute to the total score. 


\section{Characteristics of the included studies:}

The four studies included in this review were 2 randomized controlled trials (RCTs) [13,15] ; 1 quasi-experimental study [14]; and 1 study [16] of a case report. The final study sample was 278 participating child included 122 [13,15]; 155 [14] and1child [16]. Their ages ranged from 7 [14] to 18 [15] years. Studies included participants of both sexes.

The intervention performed for the experimental group of the included studies was virtual reality using the Nintendo Wii gaming technology $[\mathbf{1 3}, \mathbf{1 4}$, 15,16]; one RCT by Abdel Rahman [13] used Wii Balance Board combined with traditional physical therapy program the other included RCT by Lin and Wuang [15] used also combined exercise training program withVR-based activity, while the study by Wuang et al., [14] used the Wii games alone. The child in the case report received family-supported Wii games at home. The duration of VR session ranged from 20 minutes to 1-hour, 2-4 times/week and lasted from 6 to 8 weeks. The control group received either no intervention [14,15], a traditional physical therapy program [13] or a standard occupational therapy [14].

Measures of balance were reported in 2 studies $[13,16]$ using Bruininks-Oseretsky Test of Motor Proficiency and the Biodex BioSway Balance System. The measures of sensorimotor functions were reported in one study [14] using BruininksOseretsky Test of Motor Proficiency, Developmental Test of Visual Motor Integration, and Test of Sensory Integration Function. Strength and ability performance measures were reported in 2 studies $[15,16]$ using the handheld dynamometer and the strength and agility subtests of the BruininksOseretsky Test of Motor Proficiency. The case report [16] also reported the measure of visual perception by the Test of Visual Perception Skills, and the measure of body composition by the Body Stat QuadScan 4000. The studies characteristics are summarized in Table (3).

Table (3) shows the clinical heterogeneity present in studies design, intervention and outcome measures; thus the included studies were analyzed by using descriptive analysis.

Table (3): Summary of the included studies.

\begin{tabular}{|c|c|c|c|c|c|}
\hline \multirow{2}{*}{ Study } & \multirow{2}{*}{$\begin{array}{l}\text { Study } \\
\text { design }\end{array}$} & \multirow{2}{*}{ Participants } & \multicolumn{2}{|l|}{ Intervention } & \multirow{2}{*}{ Outcome } \\
\hline & & & Study & Control & \\
\hline $\begin{array}{l}\text { Abdel Rahman } \\
2010 \text { [13] }\end{array}$ & $\begin{array}{c}\text { Randomized } \\
\text { controlled } \\
\text { trial }(\mathrm{RCT})\end{array}$ & $\begin{array}{l}\text { - } \mathrm{n}=30 \\
\text { - Age }=10-13 \\
\text { - with mild to mod- } \\
\text { erate mental retar- } \\
\text { dation. }\end{array}$ & $\begin{array}{l}\text { Nintendo Wii-fit device using } \\
\text { the Wii Balance Board + Tra- } \\
\text { ditional physical therapy pro- } \\
\text { gram two times per week for } \\
6 \text { weeks. }\end{array}$ & $\begin{array}{l}\text { Traditional physical } \\
\text { therapy program } \\
\text { for two times per } \\
\text { week for } 6 \text { weeks }\end{array}$ & Balance \\
\hline $\begin{array}{l}\text { Wuang et al., } \\
2011 \text { [14] }\end{array}$ & $\begin{array}{l}\text { Quasi- rand- } \\
\text { omized trial }\end{array}$ & $\begin{array}{l}-\mathrm{n}=155 \\
- \text { Age }=7-12 \\
\text { - Able to follow } \\
\text { simple instruc- } \\
\text { tion. }\end{array}$ & $\begin{array}{l}2 \text { groups: } \\
\text { Nintendo Wii gaming technol- } \\
\text { ogy or Standard occupational } \\
\text { therapy 1-hour session } 2 \text { days } \\
\text { per week for } 24 \text { weeks. }\end{array}$ & No-treatment & $\begin{array}{l}\text { Sensorimotor } \\
\text { functions. }\end{array}$ \\
\hline $\begin{array}{l}\text { Lin and Wuang, } \\
2012 \text { [15] }\end{array}$ & RCT & $\begin{array}{l}-n=92 \\
- \text { Age }=13-18\end{array}$ & $\begin{array}{l}\text { Combined exercise training } \\
\text { program consisted of a } 5 \mathrm{~min} \\
\text { treadmill exercise and } 20 \\
\text { minute VR-based activity us- } \\
\text { ing Nintendo Wii gaming } \\
\text { technology } 3 \text { times a week for } \\
6 \text { weeks. }\end{array}$ & No-treatment & $\begin{array}{l}\text { Muscle } \\
\text { strength and } \\
\text { agility per- } \\
\text { formance. }\end{array}$ \\
\hline $\begin{array}{l}\text { Patti et al., } \\
2012 \text { [16] }\end{array}$ & Case report & $\begin{array}{l}-\mathrm{n}=1 \\
\text { - Age }=12 \text {-Able to } \\
\text { communicate in } \\
\text { English. }\end{array}$ & $\begin{array}{l}\text { Family-supported Nintendo Wii } \\
\text { games at home } 4 \text { times each } \\
\text { week for } 20 \text { min eac h session } \\
\text { for } 8 \text { weeks. }\end{array}$ & - & $\begin{array}{l}\text { Strength, agili- } \\
\text { ty, coordina- } \\
\text { tion, balance, } \\
\text { visual percep- } \\
\text { tual skills, } \\
\text { body compo- } \\
\text { sition. }\end{array}$ \\
\hline
\end{tabular}




\section{Effects of $V R$ versus no intervention:}

Results of a good quality study [14] compared VR versus no treatment showed that the VR Wii group had greater improvement in the motor proficiency, visual-integrative abilities, and sensoryintegrative functioning. The case study [16] reported also improvements in the child's postural stability, upper-limb coordination, manual dexterity, balance, and running speed and agility.

\section{Effects of VR versus other interventions:}

The quasi experimental study [14] of good quality, compared the VR Wii therapy with standard occupational therapy for school-aged children with DS; results revealed that the VR Wii therapy produced the largest improvements in all Developmental Test of Visual Motor Integration (VMI), Bruininks-Oseretsky Test of Motor Proficiency (BOT2), and Test of Sensory Integration Function (TSIF) subtest with the exception of manual dexterity, sensory discrimination and sensory modulation subtests compared with the standard occupational therapy.

\section{Effects of VR combined with other interventions:}

Results of the 2 good quality RCTs [13,15] included in this review showed that the use of VR Wii gamesin addition to the traditional physical therapy program could improve balance for children with DS and the use of VR based activity in a short-term exercise training program with treadmill exercise could improve muscle strength and agility performance of adolescent with DS.

\section{Effects of family-supported VR Wii games}

The only study [16] included in this review examined the use of home-based VR Wii games reported that it may produce improvements in motor skills and postural control.

\section{Discussion}

The search of this systematic review revealed a limited number of studies that investigated the effects of VR on children with DS. Only four studies were included, but despite that; the good methodological quality of these studies give moderate evidence on the effectiveness ofVR in motor rehabilitation of children with DS.

Traditional therapies in the rehabilitation of children and adolescent with DS are repetitive and lack the variability; it is difficult for them to repeat practice therapeutic activities because the nature of DS which causes developmental disabilities and cognitive impairments [17]. More motivating and effective training interventions are needed in the rehabilitation of children and adolescent with DS.

Virtual reality is an innovative tool in the rehabilitation of children with DS [18]. Virtual reality colorful environment would be fantastic for DS children. The exposure to the multiple stimuli could be gradually increased, based on motivation and cooperation of the patient [19]. This systematic review is a trial to fill the gap of knowledge between research and clinical practice in using VR in rehabilitation of children with DS.

Within the field of motor rehabilitation, VR allows motivation for practicing repeated exercises by including playing in the rehabilitation, it allows also for the complete control over the stimulus and its consistencyandthe evaluation of effects. Other benefits of VRareensuring a safe learningenvironment and the capacity to offer individualizedtreatment $[20,21]$.

There are a variety of explanations for why VR could improve motor abilities of children with DS; themultisensory feedback provided by the VR therapy mayexplain improvements in performance as well as learning, also it couldpositively affect the brain reorganization/plasticity, motorcapacity, visual-perceptual skills, social participation and personal factors [22].

Although three of the four included studies had goodmethodological quality that give moderate evidence supporting the use of VR in the rehabilitation of children with DS to improve their motor abilities including muscle strength, agility performance, postural control, balance and sensorimotor functions; resultsofthis review shouldbetakenwith caution as the current review highlights the variation in VR-based therapy (type of Wii technology and duration of session), outcome measures and follow-up in the included studies. This clinical heterogeneity limits the degree of comparison between the results of these studies and makes meta-analysis inappropriate.

\section{Conclusion:}

The current review found moderate quality evidence supporting the the use of virtual reality in motor rehabilitation of children with Down syndrome. There were few number of research related to the topic; more well-designed randomized controlled trials into the effectiveness of VR for children with DS are still needed. Future highquality research may confirm the present evidence about the benefit of VR for children with DS. 
The included studies in this systematic review showedthat VRWii gaming technology either used with or without combination of other interventions had positive effects on balance, sensorimotor functions, and muscle strength and agility performance.

\section{References}

1- HOECKER J.L.: Expert opinion. Mayo Clinic, Rochester, Minn. Disability and Rehabilitation, 29: 1139-1146, 2013.

2- HICKEY F., HICKEY E. and SUMMAR KL.: Medical update for children with Down syndrome for the pediatrician and family practitioner. Advances in Pediatrics, 59: 137-157, 2012.

3- SUMMAR K. and LEE B.: Down syndrome and other abnormalities of chromosome number. In R.M. Kliegman et al., eds., Nelson Textbook of Pediatrics, 19 th ed., pp. 399-404. Philadelphia: Saunders, 2011.

4- COSTA A.C.: On the promise of pharmacotherapies targeted at cognitive and neurodegenerative components of Down syndrome. Developmental Neuroscience, 33: 414-427, 2011.

5- WOODFORD C.: Virtual reality. Retrieved from http://www.explainthatstuff.com/virtualreality, Learning Virtual Reality: Developing Immersive Experiences and Applications for Desktop, Web, and Mobile by Tony Parisi. O'Reilly, 2015. An up-to-date introduction for VR developers that covers everything from the basics of VR to cutting-edge products like the Oculus Rift and Google Cardboard, 2016.

6- MALLOY KM., and MILLING LS.: The effectiveness of virtual reality distraction for pain reduction: A systematic review. Clinical Psychology Review, 30: 1011-1018, 2010.

7- LAUFER Y., and WEISS P.L.: Virtual Reality in the assessment and treatment of children with motor impairment: A systematic review. Journal of Physical Therapy Education, 25: 59-71, 2011.

8- DARRAH J., HICKMAN R., O'DONNELL M., VOGTLE L. and WIART L.: AACPDM methodology to develop systematic reviews of treatment interventions (Revision 1.2), Milwaukee, WI, USA: American Academy for Cerebral Palsy and Developmental Medicine. Retrieved from http://www. aacpdm.org, 2011.

9- MAHER C.G., SHERRINGTON C., HERBERT R.D., MOSELEY A.M. and ELKINS M.: Reliability of the PEDro scale for rating of quality randomizedcontrolled trials. Physical Therapy, 83: 713-721, 2003.

10- DARRAH J., HICKMAN R., O'DONNELL M., VOGTLE
L. and WIART L.: AACPDM methodology to develop systematic reviews of treatment interventions (Revision 1.2), Milwaukee, WI, USA: American Academy for Cerebral Palsy and Developmental Medicine. Retrieved from http://www. aacpdm.org., 2008.

11- VALKENET K., VAN DE PORT I.G.L., DRONKERS J.J., DE VRIES W.R., LINDEMAN E. and BACKX F.J.G. The effects of preoperative exercise therapy on postoperative outcome: A systematic review. Clin. Rehabil., 25 (2): 99-111, 2011.

12- PRINS M.R. and WURFF P. VAN DER: Females with patellofemoral pain syndrome have weak hip muscles: A systematic review. Australian Journal of Physiotherapy, 55: 9-15, 2009.

13- ABD EL-RAHMAN S.A.: Efficacy of virtual realitybased therapy on balance in children with Down syndrome. World Applied Science Journal, 10: 254-261, 2010.

14- WUANG Y.P., CHIANG C.S., SU C.Y. and WANG C.C.: Effectiveness of virtual reality using wii gaming technology in children with Down syndrome. Research in Developmental Disabilities, 32: 312-321, 2011.

15- LIN H.C. and WUANG Y.P.: Strength and agility training in adolescents with Down syndrome: A randomized controlled trial. Research in Developmental Disabilities, 33: 2236-2244, 2012

16- PATTI B., TIFFANY B., ANDREW M., KIMBERLY P.D. and JULIE W.: Motor control outcomes following Nintendo Wii use by a child with Down syndrome. Pediatric Physical Therapy, 24: 78-84, 2012.

17- ADAMOVICH S.V., FLUET G.G. and MERIANS A.S.: Sensorimotor training in virtual reality: A review. Neurorehabilitation, 25: 29-44, 2009.

18- NASH E.B., EDWARDS G.W., THOMPSON J.A. and BARFIELD W.: A review of presence and performance in virtual environments. International Journal of HumanComputer Interaction, 12: 1-41, 2000.

19- UYANIK M., BUMIN G. and KAYIHAN H.: Comparison of different therapy approaches in children with Down syndrome. Pediatric International, 45: 68-73, 2003.

20- HOLDEN M.K.: Virtual environments for motor rehabilitation: Review. Cyberpsychology \& Behavior, 8: 187211,2005 .

21- SCHULTHEIS M.T. and RIZZO A.A.: The application of virtual reality technology in rehabilitation. Rehabilitation Psychology, 46: 296-311, 2001.

22- SNIDER L., MAJNEMER A. and DARSAKLIS V.: Virtual reality as a therapeutic modality for children with cerebral palsy. Developmental Neurorehabilitation, 13: 120-128, 2001. 


\section{الواقع الأفتراضى فى التأهيل الحركى للأطفال

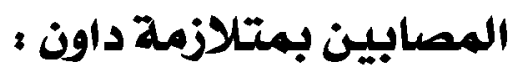 \\ مراجعة منهجية}

الهدف من الدراسة: تهذف هذه الدراسة إلى تقييم تأثير الواقع الأفتراضى فى التأهيل الحركى للأطفال المصابين بمتلازمة داون. خطة البحث: فحص منهجى اللتجارب المنشودة التى تتضمن قدرة الواقع الأفتراضى فى التأهيل الصركى للأطفال المصابين بمتلازمة داون

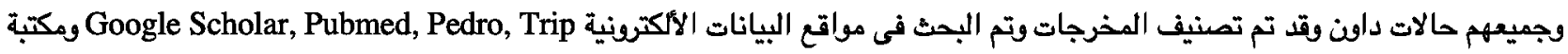
Cochrane

نتائج البحث: أربع دراسات فقط وافقت المعايير السابقة ويسبب التباين الواضح بين هذه الدراسات لم يتم عمل تحليل إحصائى مشترك

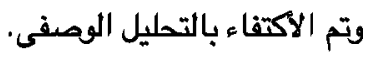

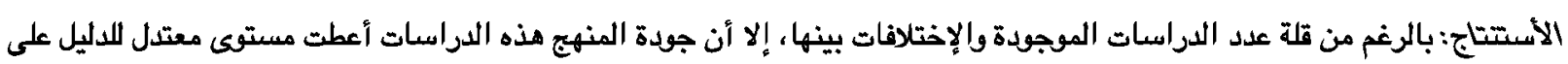
دعم تأثير الواقع الأفتراضى فى التأهيل الحركى للأطفال المصابين بمتلازمة داون. 